\section{Utility of Blueberry-derived EST-PCR Primers in Related Ericaceae Species}

\author{
Lisa J. Rowland ${ }^{\mathbf{1}}$ and Anik L. Dhanaraj \\ U.S. Department of Agriculture, Agricultural Research Service, Henry A. \\ Wallace Beltsville Agricultural Research Center, Fruit Laboratory, Bldg. \\ 010A, 10300 Baltimore Avenue, Beltsville, MD 20705
}

James J. Polashock

U.S. Department of Agriculture, Agricultural Research Service, Blueberry and Cranberry Research Center, 125A Lake Oswego Road, Chatsworth, NJ 08019

\section{Rajeev Arora}

Iowa State University, Department of Horticulture, 139 Horticulture Hall, Ames, IA 50011-1100

Additional index words. cranberry, expressed sequence tags, molecular markers, rhododendron, STS markers, Vaccinium

Abstract. Expressed sequence tag-polymerase chain reaction (EST-PCR) markers for DNA fingerprinting and mapping in blueberry (Vaccinium sp.) had previously been developed from expressed sequence tags (ESTs) produced from a cDNA library, derived from RNA from floral buds of cold acclimated plants. Because EST-PCR markers are derived from gene coding regions, they are more likely to be conserved across populations and species than markers derived from random regions of DNA, such as randomly amplified polymorphic DNA(RAPD) or amplified fragment length polymorphism (AFLP) markers. In this study, we tested whether many of the EST-PCR primer pairs developed for blueberry are capable of amplifying DNA fragments in other members of the family Ericaceae. In addition, we cloned and sequenced a selection of 13 EST-PCR fragments to determine if they showed homology to the original blueberry cDNA clones from which the EST-PCR primer pairs were derived. Closely related cranberry genotypes (two wild selections of $V$. oxycoccus $L$. and two cultivars of $V$. macrocarpon Aiton, 'Early Black' and 'Stevens') and more distantly related rhododendron genotypes (one wild selection each of Rhododendron arboreum Marsh, $R$. maximum L., and $R$. ponticum L. and three complex species hybrids, 'Sonata', 'Grumpy Yellow', and 'Roseum elegans') were used. Of 26 primer pairs tested in cranberry, $23(89 \%)$ resulted in successful amplification and eight of those (35\%) amplified polymorphic fragments among the cranberry genotypes. Of 39 primer pairs tested in rhododendron, $29(74 \%)$ resulted in successful amplification and 21 of those (72\%) amplified polymorphic fragments among the rhododendron genotypes. Approximately $\mathbf{5 0} \%$ of the 13 sequenced EST-PCR fragments were found to be homologous to the original blueberry cDNA clones. These markers should be useful for DNA fingerprinting, mapping, and assessing genetic diversity within cranberry and rhododendron species. The markers which are shown to be homologous to the blueberry cDNA clones by DNA sequencing should also be useful for comparative mapping and genetic diversity studies between some genera of the family Ericaceae.

Polymerase chain reaction (PCR)-based molecular markers, such as randomly amplified polymorphic DNAs (RAPDs), amplified fragment length polymorphisms (AFLPs), simple sequence repeat (SSR) markers, and sequencetagged-site (STS) markers, have been widely used in recent years for DNA fingerprinting, genome mapping, and population genetic studies. Their popularity is due, in part, to the technical simplicity of setting up PCRs and the small amount of genomic DNA that is required in the reactions. The many expressed sequence tag (EST) databases available today are providing sequences for developing a subcategory

Received for publication 31 Dec. 2002. Accepted for publication 22 May 2003.

${ }^{1}$ To whom reprint requests should be addressed. E-mail: rowlandj@ba.ars.usda.gov isms. Schubert et al. (2001) reported that six out of seven polymorphic EST-PCR markers developed for Norway spruce [Picea abies (L.) Karst.] were inherited in a codominant fashion.

In an effort to obtain markers with these advantages for use in blueberry (Vaccinium L., section Cyanococcus A. Gray, family Ericaceae), we have been producing ESTs using a cDNA library derived from floral buds of cold acclimated blueberry plants (Rowland et al., 2003a), and have developed a set of EST-based primer pairs with general utility for DNA fingerprinting and mapping (Rowland et al., 2003b). Recently, EST-PCR markers have been developed for many woody plant species, including loblolly pine (Pinus taeda L.) (Temesgen et al., 2001), black spruce [Picea mariana (Mill.) B.S.P.] (Perry and Bousquet, 1998), Norway spruce (Schubert et al., 2001), and sugi (Cryptomeria japonica D. Don) (Tsumura et al., 1997). Generally, amplification using EST-PCR primers must be followed by digestion with restriction enzymes to generate cleaved amplified polymorphic sequences (CAPS) markers, heteroduplex analysis, or single-stranded conformational polymorphism (SSCP) analysis to detect polymorphisms (Cato et al., 2001). In the case of blueberry, half (15 out of 30) of the tested EST-PCR primer pairs resulted in amplification of polymorphic fragments that were detectable directly after ethidium bromide staining of agarose gels (Rowland et al., 2003b). The fact that blueberry species are primarily outcrossing and exhibit low to moderate levels of self-fertility (Galletta and Ballington, 1996) may explain the high percentage of polymorphic EST-PCR markers observed without any need for additional manipulation or analysis.

Although there are many advantages to using EST-PCR markers, considerable cost is involved in terms of time, money, and other resources in developing this type of marker. RNA must be extracted from sometimes small amounts of the appropriate tissue, a cDNA library must be constructed, hundreds of clones must be picked and plasmid DNA isolated from them, the clones must be sequenced, and primers must be designed, synthesized, and tested. If the EST-PCR primers designed for one species can be used in related species, then the cost involved in developing markers for DNA fingerprinting, genetic relationship studies, mapping, etc. for those other species is significantly reduced. In addition, if the markers are shown to be homologous, they can be used for comparative mapping studies between the species. The ability to transfer mapped STS markers within the Poaceae family has been demonstrated, both between cereal species (Erpelding et al., 1996) and between cereal and forage grass species (Taylor et al., 2001). STS primers developed from black spruce cDNA sequences have been shown to direct amplification in several different conifer species. Nearly all (95\% to $97 \%$ ) of the black spruce STS primers worked in congeneric trials, while some (21\% to $33 \%$ ) worked in other Pinaceae genera as well (Perry and Bousquet, 1998). Here, we have investigated whether 
the EST-PCR primers originally developed for blueberry are useful in other Ericaceae, namely the closely related cranberry species [subfamily Vaccinioideae; tribe Vaccinieae; genus Vaccinium; section Oxycoccus (Hill) W.D.J. Koch] and the more distantly related rhododendron species (subfamily Ericoideae; tribe Rhodoreae; genus Rhododendron L.) (Anderberg, 1993). Many of the 30 original blueberry EST-PCR primer pairs and several new ones were tested in PCRs using four cranberry genotypes (two wild selections of $V$. oxycoccus and two cultivars of $V$. macrocarpon, 'Early Black' and 'Stevens') and six rhododendron genotypes (one wild selection each of $R$. arboreum, $R$. maximum, and $R$. ponticum and three complex species hybrids, 'Sonata', 'Grumpy Yellow', and 'Roseum elegans'). The percentage of primer pairs that resulted in successful amplification and in amplification of polymorphic fragments was determined. In addition, several of the EST-PCR products from cranberry and rhododendron were cloned and sequenced and their homology to the original blueberry cDNAclones, from which the primer sequences were derived, was assessed.

\section{Materials and Methods}

Plant material and genomic DNA extraction. Four cranberry genotypes [two wild selections of V. oxycoccus (NJ96-37 and NJ96-125) and two cultivars of $V$. macrocarpon ('Early Black' and 'Stevens')] and six rhododendron genotypes \{three wild selections, one each of $R$. arboreum (accession no. 70/046), $R$. maximum (accession no. 77/564), and $R$. ponticum (accession no. 76/411) and three complex species hybrids, 'Sonata' ['Purple Splendour' ( $R$. ponticum $\mathrm{x}$ unknown) $\times(R$. dichroanthum Diels], 'Grumpy Yellow' ( $R$. yakusimanum Nakaix unknown), and 'Roseum Elegans'(R. catawbiense Michx. Xunknown)\} (Salley and Greer, 1992) were evaluated in this study. Several different blueberry genotypes were used in different experiments as positive controls. Wild rhododendron selections and the 'Sonata' hybrid were originally obtained as rooted cuttings from the Rhododendron Species Botanical Garden (Federal Way, Washington D.C., courtesy Dr. S.L. Krebs of the Holden Arboretum, Kirtland, Ohio), whereas the two cultivars, 'Grumpy Yellow' and 'Roseum elegans', were obtained as potted liners from Van Veen Nursery (Portland, Ore.) and Appalachian Nurseries (Waynesboro, $\mathrm{Pa}$.). The rhododendron genotypes were maintained at the Dept. of Horticulture Research Farm, Iowa State Univ., Ames. The cranberry genotypes were maintained at the Blueberry and Cranberry Research Center, Rutgers Univ. (Chatsworth, N.J.). The blueberry genotypes were maintained at the Fruit Laboratory, USDA/ARS (Beltsville, Md.).

Blueberry and rhododendron DNA was extracted from frozen young leaves $(\approx 5 \mathrm{~g})$, collected from greenhouse-grown plants, using the CTAB procedure of Doyle and Doyle (1990). Cranberry DNA was isolated from 4-5 fresh, fully expanded leaves $(\approx 30$ $\mathrm{mg}$ ) using the CTAB method of Stewart and
Via (1993) as modified by Novy and Vorsa (1995). DNA concentrations were estimated by agarose gel electrophoresis ( $1 \% \mathrm{w} / \mathrm{v}$ gel) using known concentrations of uncut lambda DNA(Invitrogen Life Technologies, Carlsbad, Calif.) as standards.

cDNAclones, sequence analysis, and primer design. Construction of the cDNA library for EST analysis, prepared from RNA expressed in floral buds of cold acclimated plants of the highbush blueberry cultivar Bluecrop, has been previously described (Levi et al., 1999). Clones were picked at random from the unamplified library. Plasmid DNA was isolated using the QIAprep ${ }^{\circledR}$ Spin Miniprep Plasmid Kit (Qiagen, Valencia, Calif.), quantified spectrophotometrically, digested with EcoRI and XhoI restriction enzymes (New England BioLabs, Beverly, Mass.) to release the inserts, and electrophoresed through $1 \%$ agarose gels to verify the presence of inserts and the quantity of DNA.

Single-pass nucleotide sequencing of recombinant plasmid DNAs was performed from both ends of the cDNA inserts by the
Univ. of Maryland, Center for Agricultural Biotechnology-DNASequencing Facility (College Park). After trimming vector sequences, each cDNA sequence was compared against known gene sequences contained in GenBank (http: //www.ncbi.nlm.nih.gov/BLAST) (using the BLASTX algorithm (Altschul et al., 1990). ESTs with BLASTX scores $>50$ and/or Evalues $\leq 10^{-3}(P \leq 0.001)$ were considered to have significant similarity to known sequences. Primer pairs were designed from sequence data using the P3 website (http: //www-genome.wi.mit.edu/cgi-bin/primer/ primer3_www.cgi). Forward and reverse primers were designed from sequences near the end of each cDNA insert, for those inserts from which sequence was obtained from both $5^{\prime}$ and $3^{\prime}$ ends of the cDNA. If good sequence data ( $>300$ bases) were obtained from only one end of the cDNA, then both forward and reverse primers were designed as far apart as possible from only that one end. Primers were synthesized by Invitrogen Life Technologies.

Generation of EST-PCR markers. DNA amplification reactions were performed as

Table 1. Summary of blueberry cDNA clones, including their names, origin of nucleotide sequences $\left(5^{\prime}\right.$ or 3’end), putative identification from BLASTX searches, BLASTX E-values, and percent identities.

\begin{tabular}{|c|c|c|c|c|}
\hline $\begin{array}{l}\text { Clone } \\
\text { name }\end{array}$ & $\begin{array}{l}\text { Origin of } \\
\text { nucleotide } \\
\text { sequences }\end{array}$ & $\begin{array}{c}\text { Putative } \\
\text { identification }\end{array}$ & E-value $^{z}$ & $\begin{array}{c}\% \\
\text { Identity }^{\mathrm{y}}\end{array}$ \\
\hline$\overline{4 * x}$ & $5^{\prime}$ and $3^{\prime}$ & Non-identified & $\mathrm{NS}^{\mathrm{W}}$ & \\
\hline $10 *$ & $3^{\prime}$ & Phospholipid-hydroperoxide glutathione peroxidase & $3 \times 10^{-59}$ & 68 \\
\hline $14 *$ & $3^{\prime}$ & Non-identified & NS & \\
\hline $15^{*}$ & $5^{\prime}$ and $3^{\prime}$ & Pyruvate decarboxylase isozyme 1 & $1 \times 10^{-102}$ & 83 \\
\hline $20 *$ & $5^{\prime}$ and $3^{\prime}$ & Non-identified & NS & \\
\hline $21 *$ & $5^{\prime}$ and $3^{\prime}$ & Non-identified & NS & \\
\hline $22^{*}$ & $5^{\prime}$ & Dessication-responsive protein 29B & $2 \times 10^{-4}$ & 36 \\
\hline $23^{*}$ & $5^{\prime}$ and $3^{\prime}$ & Putative protein (Arabidopsis thaliana) & $2 \times 10^{-17}$ & 70 \\
\hline $25^{*}$ & $5^{\prime}$ & U6 snRNA-associated Sm-like protein & $2 \times 10^{-45}$ & 90 \\
\hline $28^{*}$ & $5^{\prime}$ & Auxin-responsive protein IAA8 & $6 \times 10^{-17}$ & 67 \\
\hline $30 *$ & $5^{\prime}$ & Putative protein (Arabidopsis thaliana) & $1 \times 10^{-28}$ & 76 \\
\hline $31 *$ & $5^{\prime}$ and $3^{\prime}$ & Aldehyde dehydrogenase & $2 \times 10^{-53}$ & 51 \\
\hline $32 *$ & $5^{\prime}$ and $3^{\prime}$ & Putative protein (Arabidopsis thaliana) & $6 \times 10^{-30}$ & 56 \\
\hline $33^{*}$ & $5^{\prime}$ and $3^{\prime}$ & MAP kinase kinase & $6 \times 10^{-47}$ & 81 \\
\hline $34 *$ & $5^{\prime}$ & Low temperature-induced $65 \mathrm{kDa}$ protein & $2 \times 10^{-13}$ & 29 \\
\hline 38 & $5^{\prime}$ and $3^{\prime}$ & Non-identified & NS & \\
\hline $39 *$ & $5^{\prime}$ and $3^{\prime}$ & Putative protein (Arabidopsis thaliana) & $9 \times 10^{-27}$ & 65 \\
\hline $42 *$ & $5^{\prime}$ and $3^{\prime}$ & Putative pollen allergen, beta expansin & $1 \times 10^{-87}$ & 65 \\
\hline $43^{*}$ & $5^{\prime}$ and $3^{\prime}$ & Calmodulin-binding protein & $6 \times 10^{-58}$ & 65 \\
\hline $44^{*}$ & $5^{\prime}$ and $3^{\prime}$ & ATP synthase alpha chain & $2 \times 10^{-67}$ & 95 \\
\hline $45^{*}$ & $5^{\prime}$ and $3^{\prime}$ & Putative RNA helicase & $7 \times 10^{-51}$ & 50 \\
\hline $47 *$ & $5^{\prime}$ and $3^{\prime}$ & Ubiquitin activating enzyme E1 & $1 \times 10^{-93}$ & 83 \\
\hline $49 *$ & $5^{\prime}$ and $3^{\prime}$ & Non-identified & NS & \\
\hline $51^{*}$ & $5^{\prime}$ and $3^{\prime}$ & Dicyanin, blue copper protein & $8 \times 10^{-27}$ & 46 \\
\hline $52 *$ & $5^{\prime}$ and $3^{\prime}$ & ABI3-interacting protein & $6 \times 10^{-66}$ & 38 \\
\hline $53^{*}$ & $5^{\prime}$ and $3^{\prime}$ & Lysophosphatidic acid acyltransferase & $1 \times 10^{-75}$ & 56 \\
\hline 133 & $5^{\prime}$ and $3^{\prime}$ & Putative protein (Arabidopsis thaliana) & $2 \times 10^{-45}$ & 56 \\
\hline 136 & $5^{\prime}$ and $3^{\prime}$ & Putative protein (Arabidopsis thaliana) & $4 \times 10^{-69}$ & 68 \\
\hline 147 & $5^{\prime}$ and $3^{\prime}$ & RNA binding protein homolog & $9 \times 10^{-36}$ & 75 \\
\hline $148 *$ & $5^{\prime}$ and $3^{\prime}$ & Phosphatidylinositol transfer-like protein & $2 \times 10^{-99}$ & 83 \\
\hline 150 & $5^{\prime}$ and $3^{\prime}$ & DNA-directed polymerase $1190 \mathrm{~K}$ chain & $2 \times 10^{-49}$ & 69 \\
\hline 169 & $5^{\prime}$ and $3^{\prime}$ & Non-identified & NS & \\
\hline 172 & $5^{\prime}$ and $3^{\prime}$ & Putative protein (Arabidopsis thaliana) & $1 \times 10^{-37}$ & 55 \\
\hline 175 & $5^{\prime}$ and $3^{\prime}$ & Non-identified & NS & \\
\hline 191 & $5^{\prime}$ and $3^{\prime}$ & Sucrose synthase & $7 \times 10^{-79}$ & 77 \\
\hline 193 & $5^{\prime}$ and $3^{\prime}$ & Vacuolar $\mathrm{H}^{+}$-pyrophosphatase & $1 \times 10^{-106}$ & 92 \\
\hline 1043 & $5^{\prime}$ and $3^{\prime}$ & Adenine phosphoribosyltransferase & $3 \times 10^{-62}$ & 84 \\
\hline
\end{tabular}

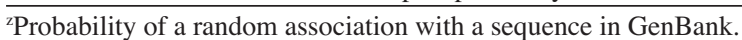

yPercent identity at the amino acid level for the available sequence.

${ }^{x}$ The asterisks mark the clones that were used to develop the original set of EST-PCR markers for blueberry. A discussion of the development of these markers and a more detailed description of these clones, including size of cDNA inserts and length of nucleotide sequences, is available in Rowland et al. (2003b).

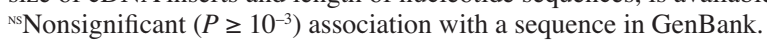


described previously (Stommel et al., 1997). Briefly, amplification reactions were carried out at least twice in $25-\mu \mathrm{L}$ volumes containing reaction buffer $(20 \mathrm{~mm} \mathrm{NaCl}, 50 \mathrm{~mm}$ Tris- $\mathrm{HCl}$ $\mathrm{pH} 9,1 \%$ Triton-X-100, $0.1 \%$ bovine serum albumin); $1.6 \mathrm{mM} \mathrm{MgCl}_{2} ; 200 \mu \mathrm{M}$ each of dATP, dCTP, dGTP, and dTTP; $0.1 \mu \mathrm{M}$ each of the forward and reverse EST primers; 0.7 units Taq DNA polymerase (Promega, Madison, Wis.); and $25 \mathrm{ng}$ template DNA. DNA was amplified by programming an MJ Research (Watertown, Mass.) PTC-100 thermal cycler for 40 cycles of a 40-s denaturation step at 92 ${ }^{\circ} \mathrm{C}, 70$-s annealing step at a temperature of $10{ }^{\circ} \mathrm{C}$ below the $\mathrm{T}_{\mathrm{m}}\left(1.0 \mathrm{M} \mathrm{Na}^{+}\right)$of the primer (forward or reverse) with the lowest $\mathrm{T}_{\mathrm{m}}$, and 120 -s extension step at $72{ }^{\circ} \mathrm{C}$. Amplification products and molecular weight standards (1-kb DNA ladder; Invitrogen Life Technologies) were separated by electrophoresis through $1.4 \%$ agarose gels.

Cloning and sequence analysis of EST-PCR products. A selection of EST-PCR amplification products, including both monomorphic and polymorphic fragments from cranberry and rhododendron, were excised from $1.4 \%$ TBE agarose gels and purified using the Ultraclean Gelspin Kit (MO BIO Laboratories, Solana Beach, Calif.) according to manufacturer's instructions. Purified fragments were cloned using the pGEM $^{\circledR}$-T Vector or the pGEM $^{\circledR}-\mathrm{T}$ Easy Vector System (Promega) according to the directions provided. Recombinant plasmids were isolated using the Ultraclean Miniprep Kit (MO BIO Laboratories). Cloned fragments were cycle-sequenced using Cy 5 labeled M13 forward and reverse primers and the SequiTherm EXCEL II Long-Read ${ }^{\mathrm{TM}}$ Kit (Epicentre Technologies, Madison, Wis.). Labeled primers were purchased from Integrated DNA Technologies (Coralville, Iowa). Sequencing reactions were separated and detected on an ALF Express Sequencer (Amersham Pharmacia Biotech, Piscataway, N.J.). Sequences were compiled using the Lasergene software package(DNASTAR, Madison, Wis.). To determine if the sequences of the PCR products were homologous to the sequences of the blueberry cDNA clones from which the EST-PCR primers were derived, sequences were compared to each other manually and by use of BLAST algorithms, Pairwise BLAST and BLASTX or BLASTN to search GenBank.

\section{Results and Discussion}

cDNA sequencing and gene identification. The cDNA library used for generating ESTs represents genes expressed in blueberry floral buds during the winter (December), when plants have reached their maximum level of cold hardiness (Muthalif and Rowland, 1994). ESTs were produced previously from clones, numbered 4, 10, 14, 15, 20, 21, 22, 23, 25, 28, $30,31,32,33,34,39,42,43,44,45,47,49,51$, 52,53 , and 148 , and used in the development of the first set of EST-PCR markers for blueberry [described in Rowland et al. (2003b)]. For this study, additional ESTs were produced from single-pass sequencing of cDNAs, numbered $38,133,136,147,150,169,172,175,191$,
Table 2. Summary of blueberry-derived EST-PCR primer pairs tested in cranberry and rhododendron. Each primer pair was scored for success (+) or failure (-) at amplifying fragments and for ability to amplify polymorphic-sized fragments (p) among the cranberry or rhododendron genotypes.

\begin{tabular}{|c|c|c|c|c|}
\hline $\begin{array}{l}\text { Clone } \\
\text { name }\end{array}$ & $\begin{array}{l}\text { Forward and reverse primer sequences } \\
\qquad\left(5^{\prime}-3^{\prime}\right)\end{array}$ & $\begin{array}{l}\text { Annealing } \\
\text { temp }\end{array}$ & Cranberry $^{2}$ & Rhododendron $^{2}$ \\
\hline 4 & $\begin{array}{l}\text { GCC GCT CTT CTC TTC CTA GC } \\
\text { CCA TCA AAC ACC ACC TAT GC }\end{array}$ & $58^{\circ} \mathrm{C}$ & - & + \\
\hline 10 & $\begin{array}{l}\text { CTT TGC CAA GTT CTG GTT GA } \\
\text { GCT AAA TGA AGT GCG GGA GA }\end{array}$ & $56^{\circ} \mathrm{C}$ & + & + \\
\hline 14 & $\begin{array}{l}\text { CTG GCC CGC AAT ATC ATA G } \\
\text { GTA GAT TGC CTC CCA CGA GA }\end{array}$ & $58^{\circ} \mathrm{C}$ & + & $+p$ \\
\hline 15 & $\begin{array}{l}\text { CTA GAG GCT GCA GTG GAA GC } \\
\text { TTG CTC GTG TCG TCC TTA TG }\end{array}$ & $58^{\circ} \mathrm{C}$ & $+\mathrm{p}$ & - \\
\hline 20 & $\begin{array}{l}\text { AAA TTG CTC GCA AAC CAA TC } \\
\text { TTT TCC AAG CAA GGG ATG G }\end{array}$ & $54^{\circ} \mathrm{C}$ & + & + \\
\hline 21 & $\begin{array}{l}\text { TCC GAT AAC CGT TAC CAA GC } \\
\text { TAT ACA GCG ACA CGC CAA AA }\end{array}$ & $56{ }^{\circ} \mathrm{C}$ & $+p$ & - \\
\hline 22 & $\begin{array}{l}\text { CTG GTC ATA CCG GGC AAC } \\
\text { GAT CAA CGG GGT TCA TGG T }\end{array}$ & $58^{\circ} \mathrm{C}$ & + & $+p$ \\
\hline 23 & $\begin{array}{l}\text { GTT AGA GAG GGT TTC GAG GA } \\
\text { AGC AAA AAC TTC ACG CCA AT }\end{array}$ & $54^{\circ} \mathrm{C}$ & + & - \\
\hline & $\begin{array}{l}\text { CGT CTC ACA GTC CCG TTT CT } \\
\text { CAA AAA CTT CAC GCC AAT CA }\end{array}$ & $54^{\circ} \mathrm{C}$ & ND & + \\
\hline 25 & $\begin{array}{l}\text { TCT CTC GGA GTT GAT CCA AAA } \\
\text { CAA CCT TTC CTC ACA CAC ACA }\end{array}$ & $57^{\circ} \mathrm{C}$ & $+\mathrm{p}$ & - \\
\hline 28 & $\begin{array}{l}\text { AAT GGA AAG AAG CTC TGA CA } \\
\text { ATC AGC CTC AGA TCC ACC AC }\end{array}$ & $54^{\circ} \mathrm{C}$ & $+\mathrm{p}$ & + \\
\hline & $\begin{array}{l}\text { TGG GGT TTC TCT TTT CTT GG } \\
\text { CCA ATT GTG AAG CAG CTG AA }\end{array}$ & $56^{\circ} \mathrm{C}$ & ND & $+p$ \\
\hline 30 & $\begin{array}{l}\text { AAT GCT GAC CCA ATC AAA GC } \\
\text { GGG TCA CGC TTG AGC TAG TG }\end{array}$ & $56^{\circ} \mathrm{C}$ & + & - \\
\hline 31 & $\begin{array}{l}\text { AGC ATT TGA CAC CAG TCA CG } \\
\text { TTA CAG GAG GGG GAT TTT }\end{array}$ & $52{ }^{\circ} \mathrm{C}$ & $+\mathrm{p}$ & $+p$ \\
\hline 32 & $\begin{array}{l}\text { CGT GGC GAA TGT ATC ATC AC } \\
\text { TGC CGC AGA TCA TGA ATA GA }\end{array}$ & $56^{\circ} \mathrm{C}$ & + & + \\
\hline 33 & $\begin{array}{l}\text { CTA ATG CAC CTG CTG ACC AA } \\
\text { ACT AAT CTC CAC GCT TCC GA }\end{array}$ & $58^{\circ} \mathrm{C}$ & + & - \\
\hline 34 & $\begin{array}{l}\text { CTA AAG ACG GGC CTG AAG TG } \\
\text { TCT GGT GAG AAC TGG TCG TG }\end{array}$ & $60^{\circ} \mathrm{C}$ & $+p$ & $+\mathrm{p}$ \\
\hline 38 & $\begin{array}{l}\text { GAC CGC TAT ATA CAT GTG TGA } \\
\text { AAA AAG GCA TCG CTT TTG AA }\end{array}$ & $52{ }^{\circ} \mathrm{C}$ & ND & $+p$ \\
\hline 39 & $\begin{array}{l}\text { TAA TGA GTC TGT GGC GAA CG } \\
\text { AAC AAG ACC AAA CCC CAC AT }\end{array}$ & $56^{\circ} \mathrm{C}$ & + & $+p$ \\
\hline 42 & $\begin{array}{l}\text { ATC TGG GGC TTG TGG ATA TG } \\
\text { CAA CCT TCT TGT GCA ATG TCA }\end{array}$ & $57^{\circ} \mathrm{C}$ & $+\mathrm{p}$ & + \\
\hline 43 & $\begin{array}{l}\text { GGC ACG AGG TCA CAG AAT GT } \\
\text { ACA ATC CCA CCC AAA AAC AA }\end{array}$ & $54{ }^{\circ} \mathrm{C}$ & + & ND \\
\hline 44 & $\begin{array}{l}\text { AGC AGC GGT ATT CTC CTC AA } \\
\text { CAC AGA ATC CAT TGA CAG CG }\end{array}$ & $58^{\circ} \mathrm{C}$ & + & + \\
\hline 45 & $\begin{array}{l}\text { CAA TGT TGG GGA GAA TGC TT } \\
\text { AAG AGC AAA ATA CAC GCA CG } \\
\text { AGA GAC TGC TGC TGG TGA CA } \\
\text { CGC ACG TAC TTG GCT ATC AG }\end{array}$ & $\begin{array}{l}56^{\circ} \mathrm{C} \\
60{ }^{\circ} \mathrm{C}\end{array}$ & $\begin{array}{l}+ \\
\mathrm{ND}\end{array}$ & $\begin{array}{l}+p \\
+p\end{array}$ \\
\hline 47 & $\begin{array}{l}\text { CTG CTG ATC CTA GCC ACC TC } \\
\text { AAA GGT TGC CCA AAA GTT CC }\end{array}$ & $56^{\circ} \mathrm{C}$ & + & - \\
\hline 49 & $\begin{array}{l}\text { GGG CAA AAC ATT TGA TTG GT } \\
\text { CTT TCC GGC TTC TCA CAA AA }\end{array}$ & $54{ }^{\circ} \mathrm{C}$ & - & $+p$ \\
\hline 51 & $\begin{array}{l}\text { GCT GCT CTT GTA CAG GGC TC } \\
\text { TTG CGC ACA CAT AAA CCT AAA }\end{array}$ & $55^{\circ} \mathrm{C}$ & $+\mathrm{p}$ & - \\
\hline 52 & $\begin{array}{l}\text { GGC AAG TGG GCA ATG ATA GT } \\
\text { TCA CAA ACT GAC CCC GTA CA }\end{array}$ & $58{ }^{\circ} \mathrm{C}$ & + & $+p$ \\
\hline 53 & $\begin{array}{l}\text { TCC AGC GCT TCT TAT CCA CT } \\
\text { GGC AGG CAT GAT TTT ACC AG }\end{array}$ & $58^{\circ} \mathrm{C}$ & + & $+p$ \\
\hline 133 & $\begin{array}{l}\text { AAA GTT AAA CGG CAG CGT GT } \\
\text { AGG CCC TGT TAA GTT TCA TCC }\end{array}$ & $56^{\circ} \mathrm{C}$ & ND & $+p$ \\
\hline 136 & $\begin{array}{l}\text { CAC AAC TGA TGC TTG GGA AG } \\
\text { ACC ATG CCC TCA CAG AAG AA }\end{array}$ & $58^{\circ} \mathrm{C}$ & ND & - \\
\hline 147 & $\begin{array}{l}\text { CTA AAT TGG GCG ACC TTC AG } \\
\text { TGG TTG ACC CTC TAC TCC AAA }\end{array}$ & $58^{\circ} \mathrm{C}$ & ND & $+p$ \\
\hline 148 & $\begin{array}{l}\text { CAA GGG TGC ACG TGA ACT TA } \\
\text { AAA AGC ATT GCA GTC ACA CG }\end{array}$ & $56^{\circ} \mathrm{C}$ & - & + \\
\hline 150 & $\begin{array}{l}\text { ATT CAG CGA ATT GCA AAG GA } \\
\text { AAA CCA GAG GGG GCT TAC AT }\end{array}$ & $54{ }^{\circ} \mathrm{C}$ & ND & $+\mathrm{p}$ \\
\hline 169 & TAG TGG AGG GTT TTG CTT GG & $57^{\circ} \mathrm{C}$ & ND & $+\mathrm{p}$ \\
\hline
\end{tabular}


193, and 1043; and good quality 5' and 3' sequences were obtained for all of them. The DNA sequences were 629 bases long on average, after removing vector sequences. Putative identities of the $11 \mathrm{cDNAs}$ were assigned by searching Genbank for similar sequences. Their identities, together with the identities of the first 26 cDNAs, are summarized in Table 1. For eight of the cDNAs, no significant sequence similarity was found, while for seven more of the clones significant sequence similarity to putative proteins from Arabidopsis thaliana was found. The remaining $22 \mathrm{cDNAs}$ appeared to encode a wide range of proteins including low temperature stress-related proteins, proteins possibly involved in signal transduction, hormone-responsive proteins, and basic structural and metabolic proteins.

Development and testing of EST-PCR markers in cranberry and rhododendron. The EST-PCR primer pairs, designed from the ends of the available nucleotide sequences, were tested in amplification reactions with DNA from four cranberry genotypes and six rhododendron genotypes (Table 2). For some of the sequences (cDNAs 23, 28, 45), primer pairs were redesigned, in an effort to obtain better amplification or more polymorphic fragments. Annealing temperatures ranged from 52 to $60{ }^{\circ} \mathrm{C}$

A total of 26 primer pairs were tested in cranberry and 39 pairs were tested in rhododendron. Fewer total primer pairs were tested in cranberry than rhododendron because a very high percentage of the primer pairs that were tested worked extremely well in cranberry; thus there did not appear to be a need for further testing. Of the 26 primer pairs tested, $23(89 \%)$ resulted in successful amplification and eight of those (35\%) amplified polymorphic fragments among the cranberry genotypes. Most of the polymorphisms occurred between the genotypes of the two species, $V$. oxycoccus and $V$. macrocarpon, and not within genotypes of the same species. Only primer pair 31 distinguished the $V$. macrocarpon cultivars while two primer pairs, 25 and 42, distinguished the V.oxycoccus selections. Amplification profiles, from PCRs using EST primer pair 42, are shown in Fig. 1A. Eighteen of the 23 primer pairs amplified similar-sized fragments to those amplified in blueberry, suggesting that most of the primer pairs result in amplification of homologous fragments.

Of the 39 primer pairs tested in rhododendron, $29(74 \%)$ resulted in successful amplification and 21 of those (72\%) amplified polymorphic fragments among the rhododendron genotypes (Fig. 1B). Twenty-one of the 29 primer pairs amplified at least some fragments that were of similar sizes to those amplified in blueberry. The higher percentage of primer pairs that were useful in cranberry (89\%), as compared to rhododendron $(74 \%)$, reflects the closer relationship between blueberry and cranberry than between blueberry and rhododendron. The higher percentage of polymorphic fragments observed among the rhododendron genotypes $(72 \%)$ than among the cranberry genotypes (35\%) may be due, at least
Table 2. Continued from previous page.

\begin{tabular}{|c|c|c|c|c|}
\hline $\begin{array}{l}\text { Clone } \\
\text { name }\end{array}$ & $\begin{array}{l}\text { Forward and reverse primer sequences } \\
\qquad\left(5^{\prime}-3^{\prime}\right)\end{array}$ & $\begin{array}{l}\text { Annealing } \\
\text { temp }\end{array}$ & Cranberry $^{z}$ & Rhododendron ${ }^{z}$ \\
\hline 172 & $\begin{array}{l}\text { CAC AAC TCC ATA ACC AGA CCA A } \\
\text { GCA GGG AAA ATT TGA CAT TCA C }\end{array}$ & $58^{\circ} \mathrm{C}$ & ND & - \\
\hline 175 & $\begin{array}{l}\text { GAC AGA TTG CGT AAC CCG TAA } \\
\text { CCA ATC CGC TTT GTC TGT TT }\end{array}$ & $56^{\circ} \mathrm{C}$ & ND & $+p$ \\
\hline 191 & $\begin{array}{l}\text { GCC TGG TGT TTG GGA ATA TG } \\
\text { TGT ACA GTT CGC TCG GTG AG }\end{array}$ & $58^{\circ} \mathrm{C}$ & ND & $+p$ \\
\hline 193 & $\begin{array}{l}\text { GAG GGA TTC AGC ACG AAG AG } \\
\text { CAA CAT CAT CAA CCC CAA CA }\end{array}$ & $56{ }^{\circ} \mathrm{C}$ & ND & $+p$ \\
\hline 1043 & $\begin{array}{l}\text { TAC ATC CAT CCG CAC ATA CG } \\
\text { ACC TGC ACG GAT TTA ACC AG }\end{array}$ & $58^{\circ} \mathrm{C}$ & ND & $+p$ \\
\hline
\end{tabular}

${ }^{2} \mathrm{ND}=$ not done

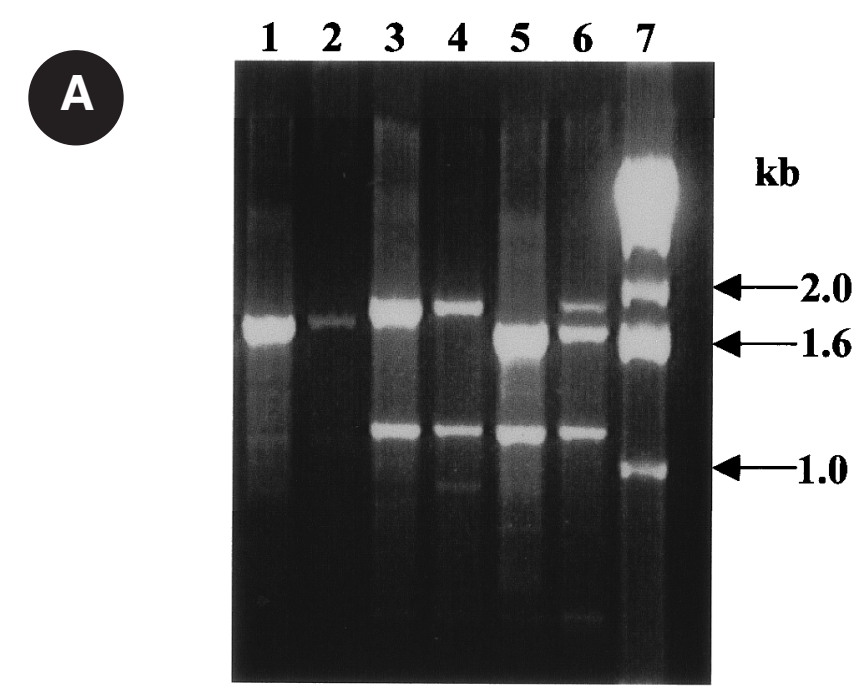

B

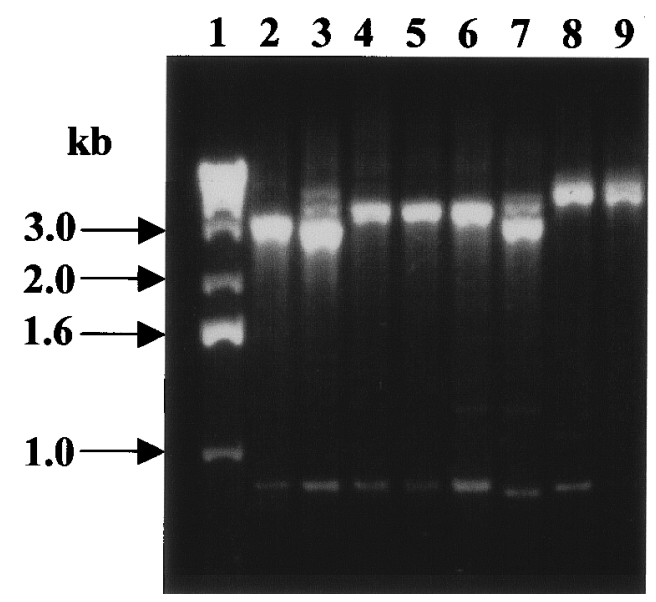

Fig. 1. Testing blueberry-derived EST-PCR primer pairs in cranberry and rhododendron. (A) Amplification products resulting from PCRs of cranberry and blueberry DNA using EST-PCR primer pair 42. From left to right, lanes were loaded as follows: blueberry selections Fla4B (1) and W85-20 (2), cranberry genotypes 'Early Black' (3), 'Stevens' (4), NJ96-37 (5), and NJ96-125 (6), and 1-kb molecular weight ladder (7). (B) Amplification products resulting from PCRs of rhododendron and blueberry DNA using EST-PCR primer pair 147. From left to right, lanes were loaded as follows: 1-kb molecular weight ladder (1), rhododendron genotypes $R$. arboreum (2), 'Grumpy Yellow' (3), 'Sonata' (4), R. maximum (5), $R$. ponticum (6), and 'Roseum elegans' (7), and blueberry cultivars 'Bluecrop' (8) and 'Berkeley' (9). 
Breeding, Cultivars, Rootstocks, \& Germplasm Resources

Table 3. Summary of EST-PCR products that were cloned and sequenced from cranberry and rhododendron, including the primers and genotypes that were used, sizes of fragments in bp, genetic variation observed among cranberry or rhododendron genotypes, and whether the PCR products were homologous to the original blueberry cDNA clones from which the primer sequences were derived.

\begin{tabular}{|c|c|c|c|c|}
\hline $\begin{array}{l}\text { EST-PCR } \\
\text { primer pair } \\
\end{array}$ & Genotype & $\begin{array}{l}\text { Approx. size of } \\
\text { fragment }^{2}\end{array}$ & $\begin{array}{l}\text { Monomorphic }(\mathrm{M}) \text { or } \\
\text { polymorphic }(\mathrm{P})\end{array}$ & $\begin{array}{c}\text { Homologous } \\
\text { to cDNA }\end{array}$ \\
\hline \multicolumn{5}{|c|}{ Cranberry PCR products } \\
\hline 28 & Stevens & 650 & $\mathrm{P}$ & No \\
\hline & & 300 & M & Yes \\
\hline 31 & Stevens & 375 & $\mathrm{P}$ & No \\
\hline 34 & NJ96-125 & 600 & $\mathrm{P}$ & Yes \\
\hline 42 & Early Black & 1900 & $\mathrm{P}$ & Yes \\
\hline 52 & Early Black & 700 & M & Yes \\
\hline \multicolumn{5}{|c|}{ Rhododendron PCR products } \\
\hline 20 & R. arboreum & 520 & M & Yes \\
\hline 28 & Grumpy Yellow & 300 & M & Yes \\
\hline 34 & Roseum Elegans & 950 & $\mathrm{P}$ & No \\
\hline 38 & Grumpy Yellow & 900 & M & No \\
\hline 42 & Sonata & 600 & M & Yes \\
\hline 45 & R. ponticum & 320 & $\mathrm{P}$ & No \\
\hline 53 & R. ponticum & 700 & $\mathrm{P}$ & No \\
\hline
\end{tabular}

${ }^{2}$ Sizes in bp.

in part, to the larger number of rhododendron genotypes examined and to the fact that each of the rhododendron genotypes represents a different species or complex interspecific hybrid.

Cloning and sequence analysis of EST-PCR products. Thirteen EST-PCR fragments, resulting from nine different EST primer pairs, were cloned and sequenced from the cranberry and rhododendron genotypes, a sufficient number to give a good indication of whether the fragments were generally homologous to the blueberry cDNAs from which the primer sequences were derived (Table 3). In making our selection of EST-PCR fragments to sequence, we chose approximately equal numbers of fragments from the cranberry and rhododendron genotypes and approximately equal numbers of monomorphic and polymorphic fragments. Specifically, six fragments (two monomorphic and four polymorphic) were cloned and sequenced from the cranberry genotypes, and seven fragments (four monomorphic and three polymorphic) were cloned and sequenced from the rhododendron genotypes. Overall, seven out of 13 or $54 \%$ of the sequenced fragments showed homology to the original blueberry clones. Four of the six (two monomorphic and two polymorphic fragments) or $67 \%$ of the fragments from the cranberry genotypes showed homology to the original cDNAclones, whereas three of the seven (all monomorphic) or $43 \%$ of the fragments from the rhododendron genotypes showed homology to the blueberry clones. Of 20 EST-PCR products cloned and sequenced from blueberry in the original study to develop the EST-PCR markers (Rowland et al., 2003b), all but three (or 85\%) were homologous to the cDNAs from which the primer sequences were designed. Thus, although these EST-PCR primers are capable of amplifying fragments from a genus as distantly related as Rhododendron, their ability to amplify ho- mologous fragments has dropped significantly from $85 \%$ in blueberry to $67 \%$ in cranberry to $43 \%$ in the rhododendron genotypes. These results highlight the importance of cloning and sequencing EST-PCR products that are to be used for comparative mapping and genetic relationship studies between species and genera and not assuming that they are homologous to the original clones from which the PCR primer sequences were derived. However, even ESTPCR markers that lack homology to the original cDNA clones may still be used for some DNA fingerprinting and genetic studies if they are reproducible, as are all the markers described in this study.

In conclusion, a high percentage of the blueberry-derived EST-PCR primer pairs resulted in successful amplification of DNA from cranberry and rhododendron, approximately $89 \%$ and $74 \%$, respectively. Approximately $50 \%$ of 13 EST-PCR fragments that were cloned and sequenced from cranberry and rhododendron were actually homologous to the original cDNA clones from blueberry. Thus, these markers should be useful for DNA fingerprinting, developing genetic linkage maps, and assessing genetic diversity within cranberry and rhododendron species. The markers which are shown to be homologous to the blueberry cDNAclones by DNA sequencing should also be useful for comparative mapping and possibly for examination of genetic relationships between species of the genus Vaccinium and between some genera of the family Ericaceae.

\section{Literature Cited}

Altschul, S.F., W. Gish, W. Miller, E.W. Myers, and D. Lipman. 1990. Basic local alignment search tool. J. Mol. Biol. 215:403-410.

Anderberg,A. 1993. Cladistic interrelationships and major clades of the Ericales. Plant Systematics and Evolution 184:207-231.

Cato, S.A., R.C. Gardner, J. Kent, and T.E. Rich- ardson. 2001. A rapid PCR-based method for genetically mapping ESTs. Theor. Appl. Genet. 102:296-306.

Doyle, J.J. and J.L. Doyle. 1990. Isolation of plant DNA from fresh tissue. Focus 12:13-15.

Erpelding, J.E., N.K. Blake, T.K. Blake, and L.E. Talbert. 1996. Transfer of sequence tagged site PCR markers between wheat and barley. Genome 39:802-810.

Galletta, G. J. and J.R. Ballington. 1996. Blueberries, cranberries, and lingonberries, p. 1-107. In: J. Janick and J.N. Moore (eds.). Fruit breeding, Volume II: Vine and small fruits crops. Wiley, New York.

Levi,A., G.R. Panta, C.M. Parmentier, M.M. Muthalif, R. Arora, S. Shanker, and L.J. Rowland. 1999. Complementary DNA cloning, sequencing, and expression of a unique dehydrin from blueberry floral buds. Physiol. Plant. 107:98-109.

Muthalif, M.M. and L.J. Rowland. 1994. Identification of dehydrin-like proteins responsive to chilling in floral buds of blueberry (Vaccinium, section Cyanococcus). Plant Physiol. 104: 1439-1447.

Novy, R.G. and N. Vorsa 1995. Identification of intracultivar genetic heterogeneity in cranberry using silver-stained RAPDs. HortScience 30: 600-604.

Perry, D.J. and J. Bousquet. 1998. Sequence-taggedsite (STS) markers of arbitrary genes: the utility of black spruce-derived STS primers in other conifers. Theor. Appl. Genet. 97:735-743.

Rowland, L.J., S. Mehra, A.L. Dhanaraj, E.L. Ogden, and R. Arora. 2003a. Identification of molecular markers associated with cold tolerance in blueberry. Acta Hort. (In press.)

Rowland, L.J., S. Mehra, A.L. Dhanaraj, E.L. Ogden, J.P. Slovin, and M.K. Ehlenfeldt. 2003b. Development of EST-PCR markers for DNA fingerprinting and genetic relationship studies in blueberry (Vaccinium, section Cyanococcus). J. Amer. Soc. Hort. Sci. 128:682-690.

Salley, H. and H. Greer. 1992. Rhododendron hybrids. Timber Press, Portland, Ore.

Schubert, R.,G. Mueller-Starck, and R. Riegel. 2001. Development of EST-PCR markers and monitoring their intrapopulational genetic variation in Picea abies (L.) Karst. Theor. Appl. Genet. 103:1223-1231.

Stewart, C.N. and L.E. Via. 1993. Arapid CTAB DNA isolation technique useful for RAPD fingerprinting and other PCR applications. BioTechniques 14:748-750.

Stommel, J.R., G.R. Panta, A. Levi, and L.J. Rowland. 1997. Effects of gelatin and BSA on the amplification reaction for generating RAPD. BioTechniques 22:1064-1066.

Taylor, C., K. Madsen, S. Borg, M.G. Moller, B. Boelt, and P.B. Holm. 2001. The development of sequence-tagged sites (STSs) in Lolium perenne L.: The application of primer sets derived from other genera. Theor. Appl. Genet. 103:648-658.

Temesgen, B., G.R. Brown, D.E. Harry, C.S. Kinlaw, M.M. Sewell, and D.B. Neale. 2001. Genetic mapping of expressed sequence tag polymorphism (ESTP) markers in loblolly pine (Pinus taeda L.). Theor. Appl. Genet. 102:664-675.

Tsumura, Y., Y. Suyama, K. Yoshimura, N. Shirato, and Y. Mukai. 1997. Sequence-tagged-sites (STSs) of cDNAclones in Cryptomeriajaponica and their evaluation as molecular markers in conifers. Theor. Appl. Genet. 94:764-772. 